\title{
TINGKAT KEPATUHAN SYARIAH DI LEMBAGA KEUANGAN SYARIAH
}

\author{
Sepky Mardian \\ Program Studi Akuntansi Syariah \\ Sekolah Tinggi Ekonomi Islam SEBI \\ Email: sepky.mardian@sebi.ac.id
}

\begin{abstract}
This study aimed to evaluate the degree of implementation of syariah compliance in Islamic banks in Indonesia toward 3 aspects i.e Syariah Supervisory Board (SSB), product and financial report. The study was analyzed by exploratoring those aspects in Islamic banks. The study found several critical issues on syariah compliance toward SSB regarding the independence, multi-served position of SSB, competences and syariah audit. The large scale of murabahah in Islamic bank financing that also was caused by depositors paradigm on savings and the issue on murabahah that was practiced differently to its basic concept are the critical issues on products. Finally, regarding to financial reporting such as income smoothing on profit distribution, lack of syariah competences of the independent auditor and treatment of murabahah margin.
\end{abstract}

Keywords: syariah compliance, SSB, product, financial report

\section{PENDAHULUAN}

Kepatuhan syariah adalah diantara aspek yang membedakan ekonomi syariah dengan ekonomi konvensional atau antara perbankan syariah dengan perbankan konvensional. (Rahman, 2008; Syafei, 2005; Abduh, 2012; Ahmed H. , 2014). Dalam konteks perbankan, ini menjadi isu krusial, karena sampai saat ini, bank syariah ditengarai masih mengikuti bank konvensional baik produk, sumber daya manusia atau operasional. Dalam banyak penelitian, masyarakat masih mempersepsikan bank syariah "sama" dengan bank konvensional (Malik, 2011; Ahmed H. , 2014). Banyak factor yang menyebabkan masih melekatnya persepsi tersebut baik, dari masyarakat sendiri, praktisi bank syariah atau regulator. Indonesia seperti Negara lainnya, masih mengakui dual banking system, dimana konvensional dan syariah sama diakui dan berlaku.

Dewan Syariah Nasional-Majelis Ulama Indonesia (DSN-MUI) dan Dewan Pengawas Syariah (DPS) adalah pihak yang ditugaskan untuk memastikan bahwa pemenuhan prinsip syariah di sektor ekonomi, khususnya perbankan, dijalankan secara maksimal. Ini menjadi tanggung jawab yang berat karena bank syariah beroperasi membawa ketinggian nama "Islam". Baik dan buruknya pemenuhan prinsip syariah di bank syariah akan memberikan dampak terhadap Islam itu sendiri. Jika ada bank syariah yang melanggar prinsip syariah, maka masyarakat tidak hanya menyalahkan bank syariah bersangkutan, tapi juga bisa menyalahkan Islam. Masyarakat akan 
beranggapan bahwa Islam tidak memiliki sistem ekonomi yang baik karena adanya pelanggaran tersebut. Inilah realita yang dihadapi. Masyarakat seperti "tidak adil" dalam memberikan hukuman. Jika ada bank syariah yang melanggar syariah, maka semua bank syariah akan dianggap sama dan mereka akan pindah ke bank konvensional. Sebaliknya, jika ada bank konvensional bermasalah, kesalahan hanya ditimpakan ke bank bersangkutan dan pindah ke bank konvensional yang lain.

Dalam prakteknya, tidak semua bank syariah berjalan mulus. Kasus yang terkait prinsip syariah juga pernah terjadi, seperti kasus BSM Bogor, BRI Syariah Yogyakarta, Bukopin Syariah Bukittinggi dan sebagainya. Terjadinya kasus tersebut, karena beragam faktor seperti tatakelola yang tidak efektif, sumber daya manusia, peran dewan pengawas syariah dan perilaku oknum masyarakat. Di sector yang lain, juga pernah terjadi kasus yang terkait syariah, seperti Golden Traders Indonesia Syariah untuk investasi emas, pencabutan sertifikat syariah oleh DSN terhadap produk MLM jasa (MLM umroh) untuk PT Arminareka Perdana dan PT Mitra Permata Mandiri (MPM).

\section{LANDASAN TEORI}

\subsection{MAQASID SYARIAH: KEPATUHAN PRINSIP SYARIAH DI BANK SYARIAH}

Maqasid syariah adalah tujuan utama yang harus direalisasikan dari wujudnya sistem ekonomi Islam, termasuk bank syariah. Implikasi dari tujuan ini lebih dari sekedar tujuan pemenuhan kebutuhan masyarakat, tetapi juga bertujuan untuk mewujudkan pertumbuhan dan keadilan dalam 5 (lima) aspek tujuan syariah dari agama (diin), akal, keturunan, harta dan kehormatan (Ahmed H. , 2014).

Dalam tingkat transaksi, implikasi maqasid ini harus terpenuhi dalam rukun dan syarat sahnya sebuah transaksi seperti kepemilikan, transaksi atas objek yang memiliki underlying asset, dan adanya perpindahan kepemilikan. Aturan ini berkaitan dengan substansi hubungan risiko dan return. Kaidah fiqh menjelaskannya dengan terminologi al-ghurmu bil ghunmi dan al-kharaj bi dhaman (Al-Suwailem, 2000), setiap keuntungan yang diperoleh harus berbanding dengan tingkat risiko yang melekat padanya. Keuntungan yang diperoleh tanpa ada risikonya, maka termasuk transaksi yang tidak sesuai dengan prinsip syariah. (Ahmed H. , 2014)

Dalam muamalah, kaidah menjelaskan bahwa asal hukumnya transaksi dalam mumalah adalah boleh kecuali ada dalil yang melarang. Alashlu fil muamalah al ibahah. Kaidah ini memberikan implikasi bahwa ruang lingkup dari transaksi muamalah sangat luas, inovasi sangat diapresiasi, transaksi baru bisa diterima. Berbeda dengan ibadah yang sangat sempit, tidak ada ruang inovasi.

Larangan transaksi dalam muamalah bisa disederhanakan pada 3 (tiga) hal yaitu riba, gharar dan maysir. Riba adalah tambahan yang diperoleh tanpa ada konsekuensi risiko yang diterima dan pengorbanan yang dilakukan. 
Riba bisa terjadi dalam transaksi jual beli atau utang piutang. Gharar atau ketidakjelasan, meliputi gharar dalam objek, gharar dalam transaksi, gharar dalam waktu penyerahan. Maysir atau judi atau spekulasi yang sebetulnya bisa termasuk dalam prinsip gharar karena adanya ketidakjelasan. Maysir yang dimaksud adalah spekulasi yang mengandung prinsip zero sum-game, atau keuntungan yang diperoleh satu pihak adalah berbanding terbalik dengan kerugian yang diderita pihak lain (Al-Suwailem, 2000).

Gambar 1 Jenis Transaksi Dilarang

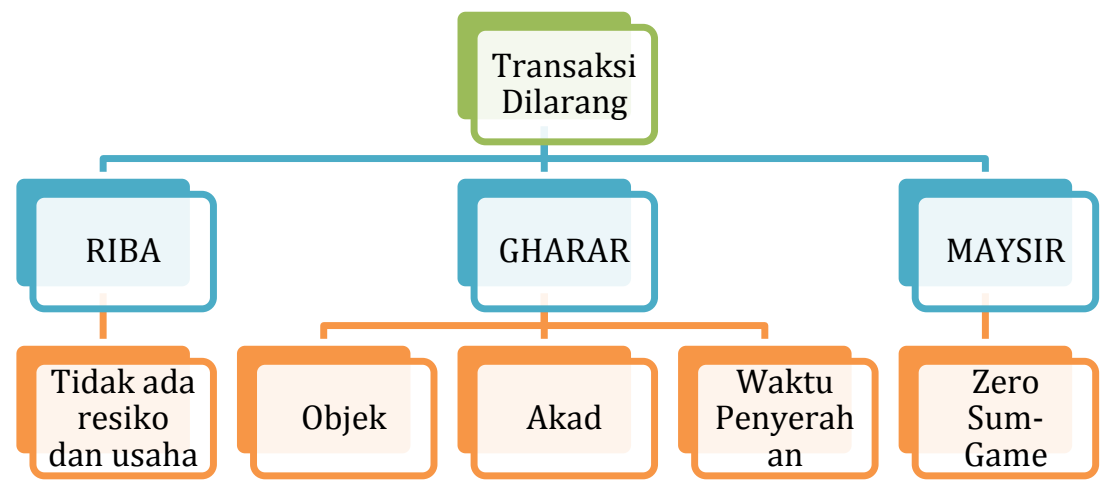

Akad dalam fiqh muamalat dikategorikan menjadi 2 (dua) yaitu akad berbasis ekuitas dan akad berbasis utang. Akad yang pertama menggunakan prinsip bagi hasil seperti mudharabah dan musyarakah. Sedangkan akad berbasis utang menggunakan prinsip keuntungan tetap (fixed income) seperti akad jual beli (murabahah, salam dan istishna) dan akad sewa (ijarah).

Gambar 2 Klasifikasi Akad

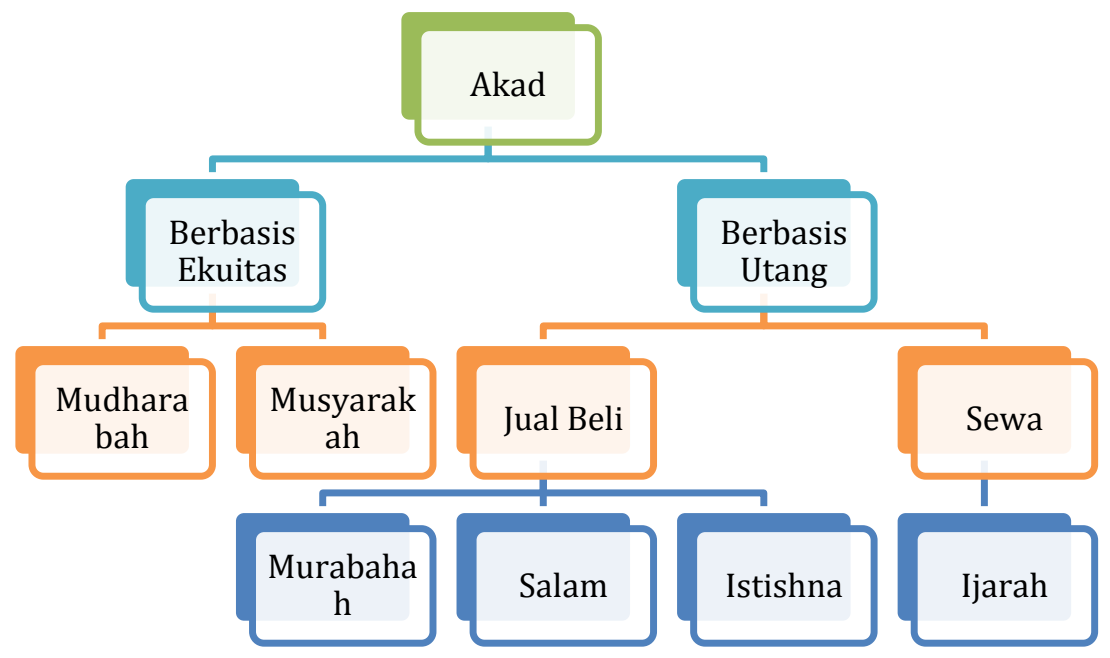




\subsection{DEWAN SYARIAH NASIONAL DAN DEWAN PENGAWAS SYARIAH}

Dewan Syariah Nasional (DSN) adalah Dewan yang dibentuk oleh MUI, yang bertugas dan memiliki kewenangan untuk memastikan kesesuaian antara produk, jasa, dan kegiatan usaha bank dengan prinsip syariah. Hal ini sebagaimana disebutkan dalam SK MUI Kep-98./MUI/2001 tentang Susunan Pengurus Dewan Syariah Nasional Majelis Ulama Indonesia (DSN-MUI), Masa Bakti Tahun 2000-2005 Tanggal 30 Maret 2001, maka kedudukan, status, dan anggota DSN MUI, adalah: 1) DSN merupakan bagian dari MUI; 2) DSN membantu pihak terkait seperti Kementerian Keuangan, Bank Indonesia (BI) (sekarang-Otoritas Jasa Keuangan) dalam menyusun peraturan/ketentuan untuk Lembaga Keuangan Syariah (LKS); 3) anggota DSN terdiri dari para ulama, praktisi dan pakar dalam bidang terkait dengan muamalah syariah; 4) anggota DSN ditunjuk dan diangkat oleh MUI selama 5 tahun masa bakti.

Adapun tugas-tugas DSN adalah: 1) menumbuhkembangkan penerapan nilai-nilai syariah dalam aktivitas keuangan dan ekonomi; 2) mengeluarkan fatwa atas jenis-jenis kegiatan keuangan; 3) mengeluarkan fatwa atas produk dan jasa keuangan syariah; 4) mengawasi penerapan fatwa yang telah dikeluarkan. Sedangkan wewenang DSN adalah: 1) mengeluarkan fatwa yang mengikat DPS di masing-masing LKS dan menjadi dasar tindakan hukum pihak terkait; 2) Mengeluarkan fatwa yang menjadi landasan bagi ketentuan/peraturan yang dikeluarkan oleh instansi yang berwenang seperti Kementerian Keuangan, Bank Indonesia (BI) (sekarangOtoritas Jasa Keuangan); 3) Memberikan rekomendasi dan/atau mencabut rekomendasi nama-nama yang akan duduk sebagai DPS pada LKS; 4) mengundang para ahli untuk menjelaskan masalah yang diperlukan dalam pembahasan ekonomi syariah, termasuk otoritas moneter/lembaga keuangan dalam maupun luar negeri; 5) memberikan peringatan kepada LKS atas penyimpangan dari fatwa DSN; 6) mengusulkan kepada instansi berwenang untuk mengambil tindakan apabila peringatan tidak diindahkan (Abidin, 2011).

Dewan Pengawas Syariah (DPS) adalah pihak yang memastikan dan mengawasi kesesuaian operasional dan produk bank terhadap prinsip syariah (Skully, 2011) yang termaktub dalam fatwa Dewan Syariah Nasional (DSN) (PBI No. 6/24/PBI/2004). Calon anggota DPS diajukan oleh bank syariah untuk memperoleh persetujuan Bank Indonesia dan penetapan dari DSN. Bank syariah wajib memiliki DPS minimal 2 (dua) orang dan sebanyakbanyaknya 5 (lima) orang.

Beberapa ketentuan yang terkait dengan DPS, yaitu: 1) Bank wajib membentuk dan memiliki DPS yang berkedudukan di KP-BS; 2) BI mengatur persyaratan, tugas, wewenang dan kewajiban DPS; 3) keanggotaan DPS diusulkan oleh Bank, disetujui oleh BI (sekarang-Otoritas Jasa Keuangan) dan ditetapkan oleh DSN sebelum diangkat oleh RUPS; 4) DPS berfungsi mengawasi kegiatan usaha bank agar sesuai syariah. Adapun tugas, wewenang dan tanggung jawab DPS, sebagai berikut: 1) memastikan kesesuaian kegiatan operasional bank syariah terhadap fatwa DSN; 2) 
menyampaikan laporan minimal setiap 6 bulan ke Direksi, Dewan Komisaris, DSN dan BI (sekarang-Otoritas Jasa Keuangan); 3) Menilai aspek syariah terhadap pedoman dan produk yang dikeluarkan bank syariah; 4) memberikan opini syariah; 5) Mengkaji produk dan jasa baru untuk dimintakan fatwa DSN; 6) Meminta penjelasan langsung pada bank dan ikut pembahasan intern (Abidin, 2011).

Di Indonesia, setidaknya DPS memiliki 3 peran penting dalam pemenuhan prinsip syariah di bank, yaitu (i) sebagai konselor dan penasehat bagi dewan direksi dan manajemen terkait pemenuhan prinsip syariah; (ii) sebagai mediator antara manajemen dengan Dewan Syariah Nasional terkait fatwa terhadap produk dan jasa yang diusulkan oleh bank syariah; dan (iii) sebagai representatif dari Dewan Syariah Nasional terkait implementasi fatwa-fatwa DSN (Arifin, 2005).

Menurut Rifat Abdul Karim (Suprayogi, 2007), terdapat 3 (tiga) model keberadaan organisasi DPS di Lembaga Keuangan Syariah, yaitu (i) advisor model, DPS bertindak sebagai advisor dan bekerja secara part time dan dating ke bank jika dibutuhkan; (ii) supervisor model, DPS berfungsi sebagai pengawas yang melakukan diskusi rutin dengan manajemen terkait pemenuhan prinsip dalam produk, jasa dan operasional; dan (iii) sharia department model, organisasi DPS yang berbentuk departemen khusus yang bekerja secara full time dan dibantu oleh staf dalam melakukan pengawasan dibawah pengawasan seorang ahli.

Sejak 1999, DSN-MUI telah menerbitkan 95 fatwa yang terkait dengan lembaga keuangan syariah (Administrator, 2014).

Grafik 1 Kelompok Jumlah Fatwa DSN-MUI

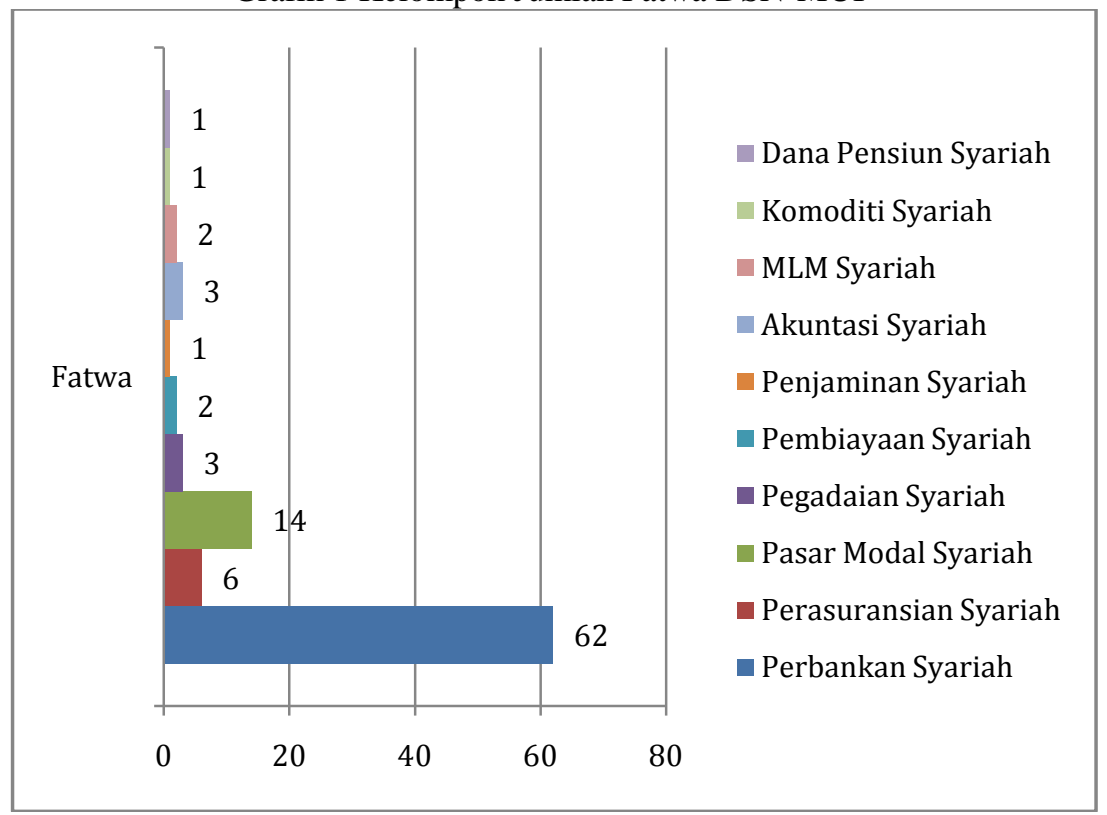

Sumber: DSN-MUI, 2014 
Grafik 2 Kelompok Jumlah Opini DSN-MUI

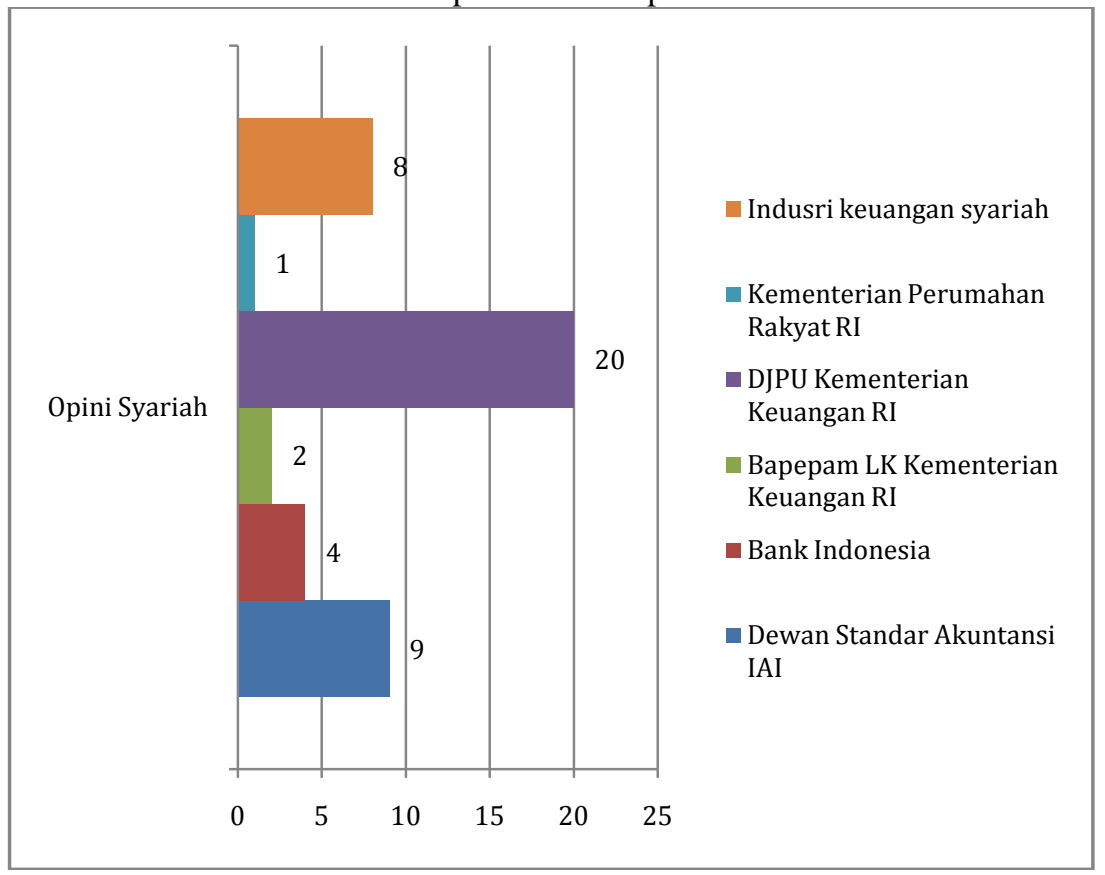

Sumber: DSN-MUI, 2014

\subsection{BANK SYARIAH DI INDONESIA}

Bank Muamalat Indonesia (BMI) merupakan bank syariah pertama yang berdiri di Indonesia pada tahun 1991 dan beroperasi tahun 1992. Regulasi yang ada saat itu adalah UU No. 7 tahun 1992 yang memungkinkan Indonesia menjalankan system perbankan dengan dual banking system. Enam tahun kemudian lahir UU No. 10/1998. Regulasi terakhir yang mengatur bank syariah adalah UU No. 21/2008.

Perkembangan bank syariah dalam 5 tahun terakhir mencapai rata-rata mencapai diatas 20\% walau mengalami pernurunan di tahun 2013. Menurut data Statistik Perbankan Syariah per Oktober 2014, telah berdiri 12 BUS, 22 UUS dan 163 BPRS dengan jumlah jaringan kantor mencapai 2.950 kantor. Total asset dan DPK yang dimiliki mencapai masing-masing lebih dari 267 triliun rupiah dan 210 triliun rupiah (OJK, 2014). Berdasarkan survei Index Islamic Finance, dari 36 negara yang disurvei dalam Islamic Finance Country, Indonesia berada di peringkat 4, di bawah Iran, Malaysia, dan Saudi Arabia. Bahkan, Indonesia di atas Bahrain dan Inggris (Hadi Suprapto, 2011).

\section{PEMBAHASAN}




\subsection{DEWAN PENGAWAS SYARIAH}

Dewan Pengawas Syariah adalah pihak yang memberikan jaminan kepada masyarakat bahwa bank syariah telah memenuhi prinsip syariah. Namun, realita yang ada saat belum ideal. Beberapa isu kritis terkait DPS adalah independensi, rangkap jabatan, masa jabatan, efektivitas kerja, kompetensi, dan prosedur pelaksanaan audit syariah.

Pertama, Isu yang terkait independensi adalah posisi DPS sebagai bagian internal dari bank yang mendapat gaji dan fasilitas keuangan. Keterkaitan struktur ini menyebabkan DPS akan kesulitan untuk bersikap independen secara mental untuk memberikan pengawasan yang independen terhadap produk dan operasional dari bank bersangkutan. Walaupun, ini secara individu secara subyektif bisa dilakukan, namun relative sulit untuk diukur dan dibuktikan.

Selanjutnya, independensi DPS terhadap DSN. Saat ini, beberapa DPS juga merangkat menjadi pengurus di DSN. Kondisi ini akan menimbulkan konflik kepentingan saat DPS yang rangkap jabatan tersebut mengajukan permohonan fatwa kepada DSN. Idealnya, pemisahan DSN dan DPS seperti yang ditunjukkan antara BI atau OJK dengan bank, dimana tidak ada pegawai BI atau OJK yang membuat regulasi yang merangkap sebagai karyawan di bank.

Kedua, isu tentang rangkap jabatan DPS di beberapa lembaga keuangan syariah yang mempengaruhi efektivitas kerja DPS di suatu bank yang tidak bisa secara full-time mengawasi operasional bank. Realita juga menunjukkan bahwa beberapa DPS memiliki rangkat jabatan DPS di beberapa lembaga keuangan syariah. Karena factor tertentu, kondisi ini masih ditolerir oleh regulasi yang ada. Terdapat 4 (empat) aturan yang membolehkan rangkap jabatan tersebut, namun masih tumpah tindih yaitu Peraturan Bank Indonesia (PBI) No.11/3/2009 tentang Bank Umum Syariah, PBI No.11/10/2009 tentang Unit Usaha Syariah, Peraturan Menteri Keuangan (PMK) No.152/PMK.010/2012 tentang Tata Kelola Perusahaan yang Baik bagi Perusahaan Perasuransian, serta Peraturan Ketua Badan Pengawas Pasar Modal dan Lembaga Keuangan (Bapepam-LK) PER.06/2012 (Administrator, 2013).

Tabel 1 Pengaturan Rangkap Jabatan DPS

\begin{tabular}{|l|l|l|}
\hline No & \multicolumn{1}{|c|}{ Regulasi } & \multicolumn{1}{c|}{ Aturan } \\
\hline 1 & PBI 11/3/2009 & $\begin{array}{l}\text { DPS minimal dua orang dan atau } \\
\text { maksimal 50 persen dari jumlah } \\
\text { direksi }\end{array}$ \\
\hline 2 & PBI 11/10/2009 & $\begin{array}{l}\text { DPS minimal dua orang dan } \\
\text { maksimal tiga orang }\end{array}$ \\
\hline 3 & PMK 152 & $\begin{array}{l}\text { DPS minimal satu orang, serta } \\
\text { jabatan rangkap hanya } \\
\text { diperbolehkan di dua perusahaan }\end{array}$ \\
\hline
\end{tabular}




\begin{tabular}{|l|l|l|}
\hline 4 & PER.06/2012 & $\begin{array}{l}\text { DPS minimal dua orang dan } \\
\text { maksimal boleh merangkap } \\
\text { jabatan di tiga perusahaan } \\
\text { pembiayaan lainnya }\end{array}$ \\
\hline
\end{tabular}

Sumber: diolah dari Republika (2013)

Selain itu, terkait dengan isu masa jabatan dari DPS. Belum ada regulasi yang mengatur lama masa jabatan DPS di sebuah bank. Hal ini bisa mengurangi sikap independensi DPS terhadap bank yang bersangkutan.

Ketiga, terkait kompetensi. Idealnya kompetensi yang dimiliki oleh seorang DPS adalah kompetensi syariah dan kompetensi tentang audit dan transaksi perbankan sekaligus. Realita menunjukkan bahwa mayoritas DPS belum memenuhi kedua kompetensi ini sekaligus. Saat ini, terdapat 4 (empat) bank syariah memiliki anggota DPS dengan latar belakang akuntansi dan atau perbankan dalam 1 (satu) tim, yaitu Bank Syariah Mandiri, Bank Syariah Mega Indonesia, Bank BRI Syariah dan Bank Bukopin Syariah (Mardian, 2014). Sisanya DPS bank syariah masih diduduki oleh DPS yang memiliki keahlian syariah saja.

Keempat, terkait audit syariah. Realita yang ada menunjukkan bahwa DPS belum dibekali prosedur audit syariah dan opini audit syariah yang standar. Sehingga, proses audit yang dilakukan oleh DPS tidak bisa diukur dan dibandingkan antara satu dengan yang lainnya. Minimal, kedepan proses audit syariah seperti proses audit yang dilakukan oleh auditor independen. Hal lain adalah audit syariah relative banyak dilakukan pada saat awal produk diluncurkan (ex-ante audit), tetapi audit saat produk dioperasional belum memadai (ex-post audit).

\subsection{PRODUK BANK SYARIAH}

Isu kritis terkait produk bank syariah adalah isu klasik dominasi murabahah dalam pembiayaan. Murabahah memang bukan transaksi yang dilarang, tetapi seharusnya akad ini menjadi akad sekunder karena bank syariah idealnya lebih banyak menggunakan akad bagi hasil. Tetapi isu ini tentu, bukan karena keengganan bank syariah saja, tetapi juga disebabkan oleh paradigm masyarakat atau nasabah yang juga belum siap dengan akad bagi hasil. Nasabah penabung belum siap dengan fluktuasi bagi hasil murni terhadap tabungan atau deposito mereka. Faktor tingkat bagi hasil masih menjadi prioritas pilihan nasabah untuk menabung di bank syariah. Sehingga ketidaksiapann ini juga ikut memaksa bank syariah untuk memperoleh return secara tetap dan murabahah adalah diantara pilihannya disamping prosedur dan risiko yang minim.

Praktik murabahah yang dijalankan bank syariah juga perlu dikritisi karena murabahah tersebut relatif tidak sesuai dengan prinsip murabahah murni dimana terhajadinya pertukaran secara nyata antara barang dengan uang. Praktiknya bank syariah baru menjalankan pembiayaan murabahah, dimana bank tidak secara langsung menyerahkan barang kepada nasabah 
tetapi hanya mencairkan uang ke rekening dan nasabah mewakili bank membeli barang yang diinginkan.

\subsection{LAPORAN KEUANGAN}

Perataan laba atau income smoothing adalah diantara isu yang terkait dengan laporan keuangan di bank syariah. Seperti dijelaskan sebelumnya karena nasabah belum siap dengan fluktuasi bagi hasil murni, maka ini memberikan insentif kepada bank syariah untuk melakukan perataan laba atau bagi hasil yang diperoleh di periode tertentu dengan mencadangkannya dan mengeluarkan cadangan tersebut pada kondisi lain saat bagi hasil turun. Kebijakan ini bisa menimbulkan penzaliman terhadap beberapa nasabah karena haknya atas bagi hasil tidak ditunaikan sebagaimana seharusnya. Namun, kebijakan ini telah mendapatkan fatwa dari DSN-MUI yang membolehkan kebijakan tersebut dengan syarat bank meminta persetujuan dengan nasabah yang hak tidak ditunaikan sebagaimana seharusnya.

Isu terkait minimnya auditor independen yang memiliki kompetensi syariah adalah realita yang dihadapi. Merespon hal tersebut, Bank Indonesia, sudah mulai melengkapi diantara partner mereka yang mendapatkan sertifikasi pendidikan dan pelatihan perbankan syariah, sehingga menurut ketentuan Surat Edaran BI No. 7/57/DPbS tanggal 22 Desember 2005, dapat melakukan audit terhadap bank yang melaksanakan kegiatan usaha berdasarkan prinsip syariah. Seperti KAP Ernst \& Young memiliki 3 orang partner yang memiliki sertifikat tersebut (BI, 2013).

Grafik 3 Big Four Indonesia dan Partner Memiliki Sertifikasi Pendidikan dan Pelatihan Syariah

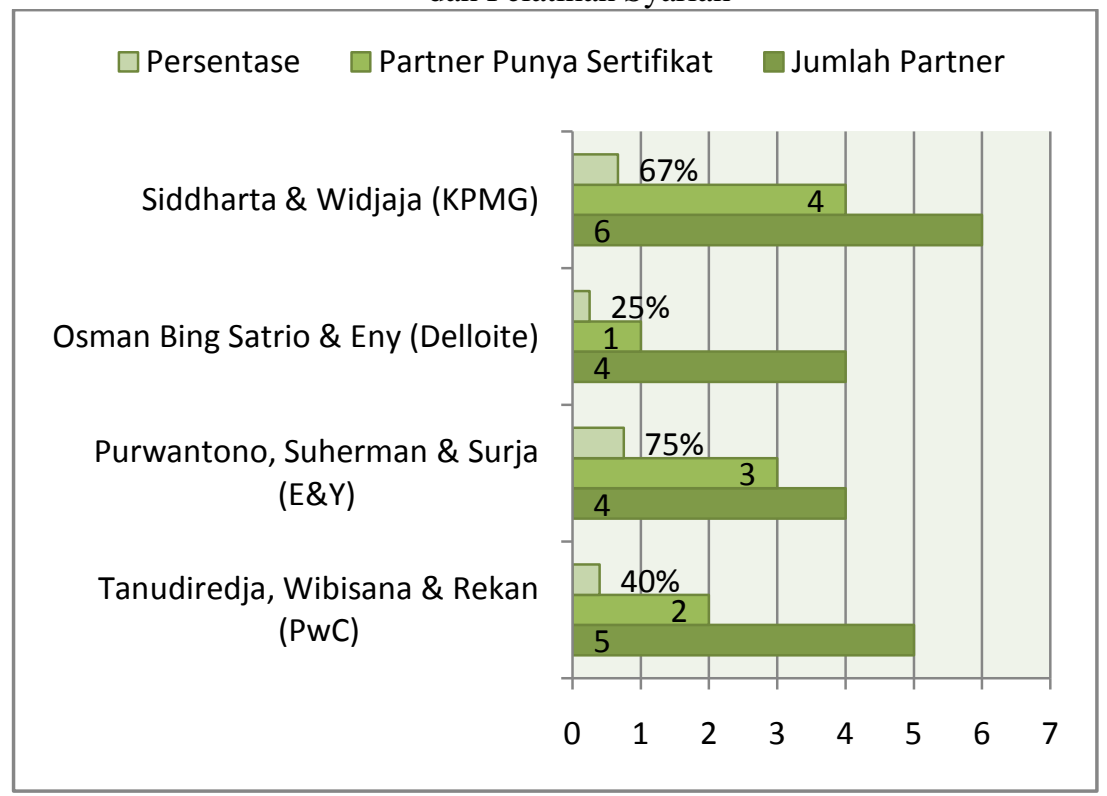

Sumber: Bank Indonesia, 2013 (diolah) 
Data yang dirilis oleh Bank Indonesia, per Februari 2013 terdapat 335 KAP yang terdaftar sebagai auditor bank di Bank Indonesia. Berdasarkan Surat Edaran BI No. 7/57/DPbS tanggal 22 Desember 2005, hanya partner KAP yang telah memperoleh sertifikasi pendidikan dan pelatihan perbankan syariah yang boleh melakukan audit terhadap bank syariah. Dengan persyaratan tersebut, diharapkan lingkup audit syariah juga mulai dimasukkan dalam perikatan auditnya (Mardian, 2013).

Isu terakhir terkait laporan keuangan adalah tentang pengaturan pengakuan marjin murabahah di PSAK 102 tentang Akad Murabahah. Revisi PSAK terbaru melegalkan bank syariah untuk mengakui marjin murabahah secara anuitas sebagaimana diatur lebih lanjut dalam PSAK 50, 55 dan 60. Revisi ini menegaskan bahwa bank syariah memang tidak melakukan akad murabahah murni tetapi pembiayaan murabahah sebagaimana disebutkan sebelumnya.

\section{SIMPULAN}

Berkembangnya ekonomi syariah, khususnya lembaga keuangan syariah menuntut adanya pemenuhan prinsip syariah. DSN-MUI dan DPS sebagai pihak yang memberikan jaminan terhadap kepatuhan syariah telah berupaya. Sampai saat ini sudah ada 95 fatwa yang diterbitkan. Namun berbagai keterbatasan terutama sumber daya menyebabkan penegakan kepatuhan syariah belum berjalan maksimal. Disamping itu banyaknya masyarakat rasional yang belum siap menggunakan prinsip syariah secara murni ikut menyumbang belum maksimalnya pemenuhan prinsip syariah. Kedepan, semua pihak termasuk masyarakat harus terus mendukung perkembangan ekonomi syariah dengan tingkat kepatuhan syariah yang tinggi.

\section{DAFTAR PUSTAKA}

Abduh, M. Z. (2012). Bank Customer Classification in Indonesia:Logistic Regression Vis-à-vis Artificial Neural Networks. World Applied Sciences Journal , 18 (7), 933-938.

Abidin, Z. (2011). Pengawasan Perbankan Syariah (Studi Pemikiran Muhammad Syafii Antonio). Maliyah, 78-94.

Administrator. (2014, May 23). http://www.iaei-pusat.org/news/siaran-pers/. Retrieved January 14, 2015, from http://www.iaei-pusat.org: http://www.iaei-pusat.org/news/siaran-pers/syariah-complianceperbankan-syariah-harus-ditingkatkan-1 ?language $=$ en

Administrator. (2014, December 13). Ijtima Sanawi (Annual Meeting) DPS X Tahun 2014. Retrieved January 14, 2015, from http://www.dsnmui.or.id:

http://www.dsnmui.or.id/index.php?mact=News,cntnt01,detail,0\&cntn 
t01 articleid $=111 \& \mathrm{cntnt} 01$ origid $=15 \& \mathrm{cntnt} 01$ detailtemplate $=$ Artikel $\&$ cntnt01 returnid $=65$

Administrator. (2013, January 2). Soal Rangkap Jabatan DPS, OJK akan Kerja Bareng Pemda. Retrieved January 14, 2015, from http://www.republika.co.id:

http://www.republika.co.id/berita/ekonomi/keuangan/13/01/02/mg01b i-soal-rangkap-jabatan-dps-ojk-akan-kerja-bareng-pemda

Ahmed, H. (2014). Islamic Banking and Shari'ah Compliance: A Product Development Perspective. Journal of Islamic Finance , 3 (2), 15-29.

AAl-Suwailem, S. (2000). Towards an Objective Measure of Gharar in Exchange. Islamic Economics Studies, 7 (1 \& 2), 61-102.

Arifin, Z. (2005). Dasar-Dasar Manajemen Bank Syariah. Jakarta: Alvabet.

Hadi Suprapto, H. B. (2011, November 16). Bisnis Syariah, Indonesia Peringkat 4 Dunia. Retrieved November 28, 2011, from vivanews.com: http://bisnis.vivanews.com

Malik, M. S. (2011). Controversies that make Islamic banking controversial: An analysis of issues and challenges. American Journal of Social and Management Sciences , 41-46.

Mardian, S. (2013). Auditor Syariah: Lulusan Syariah atau Lulusan Akuntansi. Koordinat Jurnal Komunikasi Antar Perguruan Tinggi Agama Islam Swasta , XIII (1), 179-198.

Mardian, S. (2014). Dewan Pengawas Syariah (DPS) Dan Praktik Manajemen Laba Pada Bank Syariah (Studi Pada Bank Umum Syariah 1992 - 2013). Proceeding International Conference on Islamic Economcis Studies (ICIES) 2014 (pp. 1-18). Surakarta: IAIN Surakarta.

OJK. (2014). Statistik Perbankan Syariah per Oktober 2014. Jakarta: Otoritas Jasa Keuangan.

Rahman, A. R. (2008). Shariah Audit for Islamic Financial Services: The Needs and Challenges. ISRA Islamic Finance Seminar (IIFS) (pp. 114). Kuala Lumpur: ISRA.

Skully, M. T. (2011). Corporate Governance and Islamic Bank. In M. A. Iqbal, The Foundations of Islamic Banking: Theory, Practices and Education (pp. 103-126). Cheltenham: Edward Elgar Publishing Limited.

Suprayogi, N. (2007). The Internal Shari'a Supervision Activities in Islamic Bank: A Case Study at BPRS Bhakti Makmur Sidoarjo, Indonesia. IICBiF (pp. 1-11). Kuala Lumpur: CERT. 
Syafei, A. W. (2005, April). The Responsibility and Independence of Shariah Advisors and the Shariah Review Process ini Indonesia Islamic Banks. Master Degree Thesis . Malaysia: IIUM. 